\title{
MYC functions are specific in biological subtypes of breast cancer and confers resistance to endocrine therapy in luminal tumours
}

\author{
Andrew R Green ${ }^{*}$, Mohammed A Aleskandarany ${ }^{2}$, Devika Agarwal ${ }^{3}$, Somaia Elsheikh ${ }^{1,2}$, \\ Christopher C Nolan ${ }^{1}$, Maria Diez-Rodriguez ${ }^{1}$, R Douglas Macmillan ${ }^{4}$, Graham R Ball ${ }^{3}$, Carlos Caldas ${ }^{5}$, \\ Srinivasan Madhusudan ${ }^{1}$, lan O Ellis ${ }^{1,2}$ and Emad A Rakha ${ }^{1,2}$ \\ ${ }^{1}$ Division of Cancer and Stem Cells, School of Medicine, University of Nottingham, Nottingham City Hospital, Hucknall Road, \\ Nottingham NG5 1PB, UK; ${ }^{2}$ Cellular Pathology, Nottingham University Hospitals NHS Trust, Hucknall Road, Nottingham NG5 1PB, \\ UK; ${ }^{3}$ School of Science and Technology, Nottingham Trent University, Nottingham NG11 8NS, UK; ${ }^{4}$ Breast Institute, Nottingham \\ University Hospitals NHS Trust, Hucknall Road, Nottingham NG5 1PB, UK and ${ }^{5}$ Cancer Research UK Cambridge Institute, \\ University of Cambridge, Li Ka Shing Centre, Robinson Way, Cambridge CB2 ORE
}

Background: MYC is amplified in approximately $15 \%$ of breast cancers $(B C s)$ and is associated with poor outcome. c-MYC protein is multi-faceted and participates in many aspects of cellular function and is linked with therapeutic response in BCs. We hypothesised that the functional role of c-MYC differs between molecular subtypes of BCs.

Methods: We therefore investigated the correlation between c-MYC protein expression and other proteins involved in different cellular functions together with clinicopathological parameters, patients' outcome and treatments in a large early-stage molecularly characterised series of primary invasive BCs $(n=1106)$ using immunuohistochemistry. The METABRIC BC cohort $(n=1980)$ was evaluated for MYC mRNA expression and a systems biology approach utilised to identify genes associated with MYC in the different BC molecular subtypes.

Results: High MYC and c-MYC expression was significantly associated with poor prognostic factors, including grade and basal-like BCs. In luminal A tumours, c-MYC was associated with ATM $(P=0.005)$, Cyclin B1 $(P=0.002)$, PIK3CA $(P=0.009)$ and Ki67 $(P<0.001)$. In contrast, in basal-like tumours, $c-M Y C$ showed positive association with $C y c l i n E(P=0.003)$ and $p 16(P=0.042)$ expression only. C-MYC was an independent predictor of a shorter distant metastases-free survival in luminal $A L N+$ tumours treated with endocrine therapy (ET; $P=0.013$ ). In luminal tumours treated with $E T, M Y C m R N A$ expression was associated with $B C$ specific survival $(P=0.001)$. In ER-positive tumours, MYC was associated with expression of translational genes while in ERnegative tumours it was associated with upregulation of glucose metabolism genes.

Conclusions: c-MYC function is associated with specific molecular subtypes of BCs and its overexpression confers resistance to ET. The diverse mechanisms of c-MYC function in the different molecular classes of BCs warrants further investigation particularly as potential therapeutic targets.

*Correspondence: Dr AR Green; E-mail: andrew.green@nottingham.ac.uk

Received 30 September 2015; revised 11 January 2016; accepted 9 February 2016; published online 8 March 2016

(c) 2016 Cancer Research UK. All rights reserved 0007-0920/16 
In a meta-analysis of 3797 patients, V-Myc Avian Myelocytomatosis Viral Oncogene Homolog $(M Y C)$ is amplified in $15.7 \%$ of breast cancers (BCs) and is associated with higher tumour grade, advanced stage and progesterone receptor (PgR)-negative tumours resulting in an association with poor overall survival and disease recurrence independent of existing prognostic factors (Deming et al, 2000). The c-MYC protein is multi-faceted and participates in many aspects of cellular function, including replication, growth, metabolism, differentiation and apoptosis (Liao and Dickson, 2000). The mechanisms of c-MYC action in controlling these different roles remain poorly understood. However, it may be context or isoform dependent whether c-MYC promotes cell proliferation or apoptosis (Deming et al, 2000; Liao and Dickson, 2000; Patel et al, 2004).

The expression of c-MYC is regulated by oestrogen via the phosphatidylinositol-4,5-bisphosphate 3-kinase (PI-3 kinase) pathways, among other signalling pathways, promoting cell proliferation and survival (Liao et al, 2000). Antioestrogen treatment, including aromatase inhibitors, tamoxifen and faslodex, all downregulate MYC mRNA inducing cell cycle arrest (Carroll et al, 2002). There is also strong evidence that c-MYC has a role in the development of antioestrogen resistance where it is frequently overexpressed during progression and distant relapse of oestrogen receptor (ER)-positive BCs treated with adjuvant hormonal therapy (Planas-Silva et al, 2007). Clinical evidence also suggests that c-MYC and B-cell CLL/ lymphoma 2 (Bcl-2) act in concert to promote lymph node metastasis in early BCs (Sierra et al, 1999). c-MYC overexpression can also cause DNA damage and subsequently trigger apoptosis via DNA damage response pathways. ATM serine/threonine kinase (ATM), a critical DNA double-strand break repair protein, is upregulated in response to such DNA damage and is necessary for p53 activation and suppression of tumour development.

In a recent study, it was demonstrated that c-MYC expression was upregulated through the cross-talk between ER and human epidermal growth factor receptor 2 (HER2) in BC cells (Chen et al, 2015). Cross-talk between ER and HER2 regulates c-MYC-mediated glutamine metabolism in aromatase inhibitor-resistant BC cells.

Therapeutic strategies aimed at targeting c-MYC have emerged, including interfering with c-MYC synthesis, dimerisation, stability and transcriptional activity (Vita and Henriksson, 2006; Albihn et al, 2010; Boddupally et al, 2012; Dang, 2012). However, the effectiveness of targeting c-MYC using single agents and failure to achieve long-lasting efficacy is observed because MYC function controls the expression of multiple genes and cancer cells can recover from oncogene addiction.

Thus targets aimed at inhibiting downstream signalling pathways in c-MYC-dependent tumours such as stress-response, metabolism and cell cycle pathways are currently the focus for new therapeutic opportunities (Dang, 2012). Several clinical trials focussed on these biological processes are currently underway (Horiuchi et al, 2014).

In this study, we hypothesised that the functional role of c-MYC differs between molecular subtypes of BCs and would influence the response for different type of adjuvant therapeutic regimens. We therefore investigated the correlation between MYC mRNA and c-MYC protein expression and other proteins involved in cell proliferation, DNA damage and apoptosis, in addition to clinicopathological parameters, outcome and treatments in a large cohort of molecularly characterised early-stage invasive primary breast carcinoma.

\section{MATERIALS AND METHODS}

MYC gene expression. MYC gene expression was evaluated in a cohort of 1980 BC samples using the Molecular Taxonomy of Breast Cancer International Consortium (METABRIC) cohort
(Curtis et al, 2012). RNA from fresh frozen tumours were subject to transcriptional profiling using the Illumina HT-12 v3 platform (San Diego, CA, USA), and the data were preprocessed and normalised as described previously (Curtis et al, 2012). In this cohort, patients with ER-positive and/or lymph node-negative tumours did not receive adjuvant chemotherapy, whereas those with ER-negative and/or lymph node-positive tumours received adjuvant chemotherapy.

\section{c-MYC protein expression}

Study patients. Immunohistochemistry was conducted using a large cohort of patients comprising a well-characterised consecutive series of early stage (TNM Stages I-III excluding T3 and T4 tumours) sporadic primary operable invasive BCs from patients (age $\leqslant 70$ years) enrolled into the Nottingham Tenovus Primary Breast Carcinoma Series who presented at the Nottingham City Hospital between 1989 and $1998(n=1106)$ and managed in accordance to a uniform protocol. Patients' clinical history, tumour characteristics, information on therapy and outcomes are prospectively maintained. Outcome data were collected on a prospective basis and included development and time to distant metastasis (DM) and BC-specific survival (BCSS). DM-free survival is defined as the time (in months) from the date of primary surgery to the appearance of DM. The BCSS is defined as the time (in months) from the date of primary surgery to the date of BC-related death. Luminal tumours were defined as ER+; triple-negative status were all those tumours not expressing ER, PgR and HER2; and HER2 + status was defined as all tumours overexpressing HER2 irrespective of ER status. Patients with luminal tumours had the best BCSS followed by those with triple-negative tumours (Supplementary Figure S1). Patients with HER2 + tumours had the poorest outcome.

Validating antibody specificity. The specificity of the anti-c-MYC primary antibody (Clone 9E100; Abcam Ltd, Cambridge, UK) was validated using western blotting (WB). WB was performed on whole-cell lysates of MDA-MB-468 human BC cell line (obtained from the American Type Culture Collection; Rockville, MD, USA) using 1:500 dilution of the primary antibody dilution, and 1:15000 horseradish peroxidase-conjugated secondary antibody (SA) (Li-cor Biosciences, Cambridge, UK). 5\% milk (Marvel Original Dried Skimmed Milk, Premier Food Groups Ltd, St Albans, UK) was used for blocking. HRP-conjugated Anti-Rabbit $\beta$-actin (Clone AC-15; Sigma, Gillingham, UK) at $1: 5000$ was used as a house-keeping protein. A protein ladder (PageRuler Plus Prestained Protein Ladder, ThermoScientific, Waltham, MA, USA) was included. Chemiluminescence was used to visualise bands using Odyssey Fc (Li-cor Biosciences, Lincoln, NE, USA), which showed a single specific band at the right size $(41 \mathrm{KDa})$ for c-MYC protein, confirming the specificity of the antibody (Supplementary Figure S2A).

Tissue arrays and immunohistochemistry. Tumour samples were arrayed as previously described (Abd El-Rehim et al, 2005). In brief, tissue cores with a diameter of $0.6 \mathrm{~mm}$ were punched from the representative tumour regions of each donor block. Cores were precisely arrayed into a new recipient paraffin blocks using a tissue microarrayer (Beecher Instruments, Sun Prairie, WI, USA). Immunohistochemical staining was performed on $4-\mu \mathrm{m}$ thick sections using Novolink polymer detection system (Leica Biosystems, Newcastle, UK, RE7150-K), composed of Peroxidase Block, Post Primary Block, Novolink Polymer, 3,3'-diaminobenzidine (DAB) chromogen and substrate buffer and Novolink haematoxylin. Briefly, tissue slides were deparaffinised with xylene and rehydrated through three changes of alcohol. Heat-induced antigen epitope retrieval was performed in citrate buffer $(\mathrm{pH}$ 6.0) for 20 min using a microwave oven. Endogenous peroxidase activity 
was blocked by Peroxidase Block for 5 min. Slides were washed with Tris-buffered saline (TBS, $\mathrm{pH}$ 7.6), followed by application of Protein Block for $5 \mathrm{~min}$. Following another TBS wash, mouse monoclonal primary antibody for c-MYC (Clone 9E100; Abcam Ltd) at 1:100 in Leica antibody diluent (RE7133) was applied and incubated for $45 \mathrm{~min}$. Slides were washed with TBS followed by incubation with Post Primary Block for $30 \mathrm{~min}$ followed by a TBS wash. Novolink polymer was applied for $30 \mathrm{~min}$. DAB working solution made up of $1: 20 \mathrm{DAB}$ chromogen in DAB substrate buffer was prepared and applied for $5 \mathrm{~min}$. Slides were counterstained with Novolink haematoxylin for $6 \mathrm{~min}$, dehydrated and coverslipped. Negative (omission of the primary antibody) and positive controls were included according to the manufacturer's datasheet of each antibody. Immunhistochemical staining and dichotomisation of the other biomarkers included in this study were as per previous publications (Rakha et al, 2007; Elsheikh et al, 2008; Rakha et al, 2009; Aleskandarany et al, 2010a,b, 2011, 2012; Habashy et al, 2013; Barros et al, 2014; Supplementary Table S1).

Evaluation of immunohistochemical staining. Assessment of staining was estimated subjectively on intensity corresponding to negative, weak, moderate and strong nuclear and/or cytoplasmic staining. Dichotomisation of c-MYC protein expression was based on the mean resulting in negative/weak (MYC negative) and moderate/strong (MYC positive) groups, which were selected prior to analysis.

Artificial neural network (ANN) model. A nonlinear ANN modelling-based approach was utilised to identify those gene probes associated with high $M Y C$ expression in ER-positive and -negative disease using the METABRIC cohort. A total of 48803 probes were screened for each sample. The data-mining algorithm comprised a three layer multilayer perception architecture modified with a feed forward back-propagation algorithm and a sigmoidal transfer function, as previously described (Lancashire et al, 2010; Abdel-Fatah et al, 2014). The network momentum and learning rate were, respectively, set as 0.1 and 0.5 . A parsimonious structure using two hidden nodes and three split Monte Carlo Cross validation were utilised to prevent over fitting. The output node was coded as 0 if a case was low MYC expression (median) and as 1 if it was above the median expression value. Inputs were ranked in ascending order based on their average classification error for the test subset. The top 200 predictive genes identified were then applied to an ANN-based network inference algorithm as described in earlier studies. This model predicted a weighted link (direction and magnitude) between each of the top 200 gene probe markers associated with $M Y C$ expression and every other marker in the top 200. The 100 strongest interactions based on the magnitude were then visualised as a map with Cyto-scape (Smoot et al, 2011).

External validation cohorts. For external validation of MYC mRNA expression, bc-GenExMiner v3.0 (Breast Cancer GeneExpression Miner v3.2) online data set (http://bcgenex.centregauducheau.fr) was used. In this study, the gene correlation-targeted analysis offering the possibility to evaluate the correlation between MYC and candidate genes in ER + and ER - BCs was used (Jezequel et al, 2012).

Statistical analysis. Statistical analysis was performed using the SPSS 21.0 statistical software (SPSS Inc., Chicago, IL, USA). Univariate and multivariate analyses were performed by chisquared test, Log rank and Cox regression analysis, respectively. Survival curves were analysed by the method of Kaplan-Meier. A $P$-value $<0.01$ was considered significant. This study complied with reporting recommendations for tumour marker prognostic studies criteria (McShane et al, 2005). Recursive partitioning (Hothorn et al, 2006) was used to identify a cutoff in gene expression values such that the resulting subgroups have significantly different survival courses.

Ethics. This study was approved by the Nottingham Research Ethics Committee 2 under the title 'Development of a molecular genetic classification of breast cancer'.

\section{RESULTS}

MYC expression and clinicopathological parameters. High MYC mRNA expression was observed in 260 out of 1977 (13.1\%) tumours. Positive cytoplasmic and nuclear expression of c-MYC protein was observed in 559 out of 1106 (50.5\%) of invasive BC cases while 547 (49.5\%) were negative Supplementary Figures S2B and $\mathrm{C}$.

There was significant association between MYC mRNA and c-MYC protein expression with poor prognostic indicators of BCs. High MYC mRNA expression was associated with high grade $(P<0.001)$ and Nottingham Prognostic Index $(P=0.001)$ but not size or lymph node stage (Table 1). Positive c-MYC protein expression was significantly associated with higher tumour grade $(P=0.043)$, mitotic frequency scores $(P=0.004)$, nuclear pleomporphism $(P=0.012)$ and lymph node stage $(P=0.046$, Table 1$)$. c-MYC was also significantly associated with histological tumour type where more expression was observed in medullary-like tumours (22 out of $31,71.0 \%$ ) but was less likely to be expressed in lobular tumours (41 out of 106, 38.7\%). However, there was no association between c-MYC and patient age, tumour size, tubule formation or lymphovascular invasion.

MYC expression and biomarkers. High MYC mRNA expression was significantly associated with ER and PgR-negative tumours (both $P<0.001)$, HER2-positive $(P=0.001)$ as well as triplenegative tumours $(P<0.001$, Table 1$)$. There was no association between c-MYC protein expression with ER, PgR nor HER2 (Table 1). Positive c-MYC protein expression was associated with markers of basal-like phenotype, including cytokeratin 5/6 and epidermal growth factor receptor (EGFR; $P=0.002$ and 0.001 , respectively, Table 2 ).

c-MYC expression was significantly expressed in breast tumours with high ATM and PI-3 kinase (both $P=0.001$, Table 2). Cell cycle regulators p16, Cyclin B1 and Cyclin E were also significantly expressed in breast tumours with positive expression of c-MYC $(P=0.018, P=0.023$ and $P=0.001$, respectively). Tumours with high c-MYC showed high expression of Ki67 $(P<0.001)$. There was no association between c-MYC expression and BCL2, p53, p21, pAKTs473 or Retinoblastoma (Rb).

MYC expression in molecular BC subtypes. In terms of the intrinsic subtypes (PAM50), high MYC mRNA expression was significantly expressed in basal tumours $(P<0.001)$, whereas low expression was associated with luminal A and HER2 tumours (both $P<0.001$ ). There was no association between $M Y C$ expression and luminal B tumours.

Those biomarkers that were associated with high c-MYC expression in the unselected breast tumours were further investigated in the different $\mathrm{BC}$ molecular classes. This showed differential association between molecular classes. In luminal A $(\mathrm{ER}+/ \mathrm{HER} 2-)$ tumours, c-MYC expression was significantly associated with ATM $(P=0.005)$, Cyclin B1 $(P=0.002)$, PIK3CA $(P=0.009)$ and Ki67 $(P<0.001)$ but not Cyclin E nor p16 (Table 2). In contrast, in basal-like tumours, c-MYC expression was associated with positive Cyclin $\mathrm{E}(P=0.003)$ and p16 $(P=0.042)$ expression but not with ATM, Cyclin B1, PI-3 kinase or Ki67 (Table 2). In HER2 + tumours, positive c-MYC expression was associated with ATM $(P=0.001)$ and $\operatorname{Ki67}(P=0.030)$ expression only. 
Table 1. c-MYC expression in relation to clinicopathological parameters

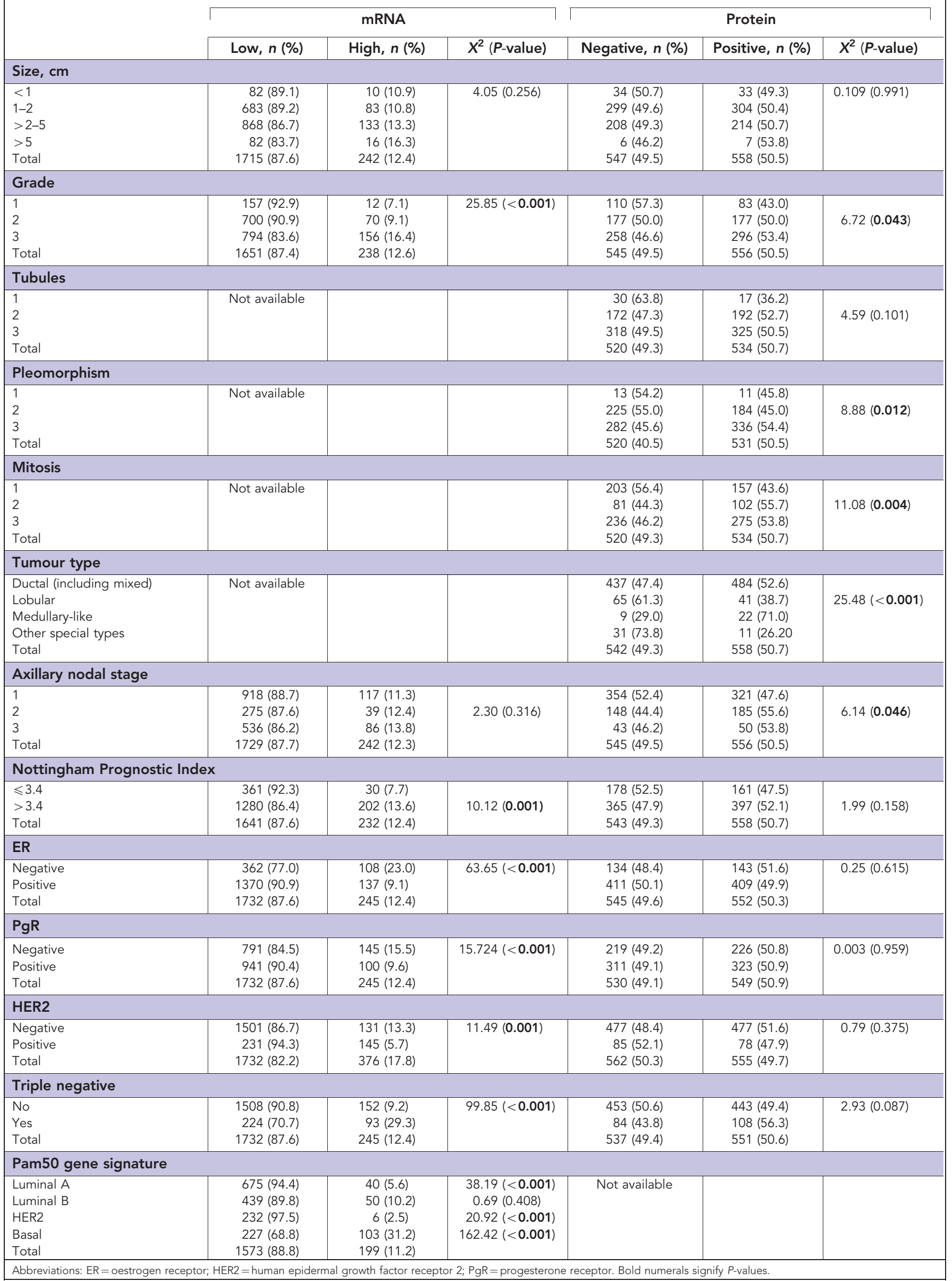


Table 2. c-MYC expression in relation to molecular breast cancer subtypes and biomarkers

\begin{tabular}{|c|c|c|c|c|c|c|c|c|c|c|c|c|}
\hline & \multicolumn{3}{|c|}{ All cases } & \multicolumn{3}{|c|}{ Luminal A } & \multicolumn{3}{|c|}{ Basal-like } & \multicolumn{3}{|c|}{ HER2 + } \\
\hline & \multirow[b]{2}{*}{ Negative } & \multirow[b]{2}{*}{ Positive } & \multirow[b]{2}{*}{$\begin{array}{c}X^{2} \\
(P \text {-value })\end{array}$} & \multicolumn{3}{|c|}{ c-MYC } & \multicolumn{3}{|c|}{ c-MYC } & \multicolumn{3}{|c|}{ c-MYC } \\
\hline & & & & Negative & Positive & $\begin{array}{c}X^{2} \\
(P \text {-value })\end{array}$ & Negative & Positive & $\begin{array}{c}X^{2} \\
(P \text {-value })\end{array}$ & Negative & Positive & $\begin{array}{c}X^{2} \\
(P \text {-value })\end{array}$ \\
\hline \multicolumn{13}{|l|}{ ATM } \\
\hline Negative & $204(55.9)$ & $161(44.1)$ & $11.68(0.001)$ & $120(58.0)$ & $87(42.0)$ & $7.71(0.005)$ & $43(46.7)$ & 49 (53.3) & $0.15(0.697)$ & $37(60.7)$ & $24(39.3)$ & $11.45(0.001)$ \\
\hline Positive & $143(42.9)$ & $190(57.1)$ & & $108(44.8)$ & $133(55.2)$ & & $19(43.2)$ & $25(56.8)$ & & $12(27.3)$ & $32(72.7)$ & \\
\hline Total & 347 (49.7) & $351(50.2)$ & & $228(50.9)$ & $220(49.1)$ & & $62(45.6)$ & $74(54.4)$ & & $49(46.7)$ & $56(53.3)$ & \\
\hline \multicolumn{13}{|l|}{ PIK3CA } \\
\hline $\begin{array}{l}\text { Negative/ } \\
\text { low }\end{array}$ & $134(59.8)$ & $90(40.2)$ & $13.67(0.001)$ & $132(46.8)$ & $150(53.2)$ & $9.47(0.009)$ & $13(50.0)$ & $13(50.0)$ & $0.67(0.717)$ & $12(63.2)$ & $7(36.8)$ & $2.93(0.302)$ \\
\hline Medium & $117(44.7)$ & 145 (55.3) & & $92(45.5)$ & $110(54.5)$ & & $12(40.0)$ & $18(60.0)$ & & $10(40.0)$ & $15(60.0)$ & \\
\hline High & $239(46.6)$ & $274(53.4)$ & & $103(59.9)$ & $69(40.1)$ & & $51(42.1)$ & 70 (57.9) & & 53 (52.5) & $48(47.5)$ & \\
\hline Total & $490(49.0)$ & 509 (51.0) & & $327(49.8)$ & $329(50.1)$ & & 76 (42.9) & $101(57.1)$ & & 75 (51.7) & $70(48.3)$ & \\
\hline \multicolumn{13}{|c|}{ Cyclin B1 } \\
\hline Negative & $200(51.2)$ & $191(48.8)$ & $5.21(0.023)$ & $136(54.6)$ & $113(45.4)$ & $9.55(0.002)$ & 28 (36.4) & $49(63.6)$ & $0.57(0.449)$ & $32(56.1)$ & $25(43.9)$ & $0.56(0.455)$ \\
\hline Positive & $138(42.6)$ & $186(57.3)$ & & $83(40.1)$ & $124(59.9)$ & & 24 (42.9) & $32(57.1)$ & & $27(49.1)$ & $28(50.9)$ & \\
\hline Total & 338 (47.3) & $377(52.7)$ & & $219(48.0)$ & $237(52.0)$ & & $52(39.0)$ & $81(41.0)$ & & 59 (34.5) & $112(65.5)$ & \\
\hline \multicolumn{13}{|l|}{ Cyclin E } \\
\hline Negative & $215(52.4)$ & 195 (47.6) & $10.55(\mathbf{0 . 0 0 1 )}$ & 147 (49.3) & $151(50.7)$ & $1.50(0.220)$ & $26(61.9)$ & $16(38.1)$ & $8.67(0.003)$ & $36(50.0)$ & $24(40.0)$ & $1.95(0.163)$ \\
\hline Positive & $36(34.6)$ & $68(65.4)$ & & $13(38.2)$ & $21(61.8)$ & & 16 (31.4) & $35(68.6)$ & & $6(40.0)$ & $9(60.0)$ & \\
\hline Total & 251 (48.8) & $263(51.2)$ & & $160(48.2)$ & $172(51.8)$ & & $42(45.2)$ & $51(54.8)$ & & $42(56.0)$ & $33(44.0)$ & \\
\hline \multicolumn{13}{|l|}{ P16 } \\
\hline Negative & $356(51.5)$ & 335 (48.5) & $5.62(0.018)$ & $264(51.1)$ & 253 (48.9) & $3.37(0.066)$ & 37 (55.2) & $30(44.8)$ & $4.15(0.042)$ & $47(49.5)$ & $48(50.5)$ & $0.47(0.494)$ \\
\hline Positive & $142(43.6)$ & $184(56.4)$ & & $62(42.5)$ & $84(50.8)$ & & $46(39.7)$ & $70(60.3)$ & & $32(55.2)$ & $26(44.8)$ & \\
\hline Total & $498(49.0)$ & $519(51.0)$ & & $326(49.2)$ & $337(50.8)$ & & $83(45.4)$ & $100(54.6)$ & & $79(51.6)$ & $74(48.4)$ & \\
\hline \multicolumn{13}{|l|}{ Ki67 } \\
\hline Negative & $176(59.7)$ & $119(40.3)$ & $20.71(<0.001)$ & $149(58.9)$ & $104(41.1)$ & $13.45(<0.001)$ & $10(55.6)$ & 8 (44.4) & $1.59(0.207)$ & 15 (71.4) & $6(28.6)$ & $4.73(0.030)$ \\
\hline Positive & $266(43.5)$ & 345 (56.5) & & $148(43.7)$ & $191(56.3)$ & & $58(40.0)$ & $87(60.0)$ & & $52(49.6)$ & $62(54.4)$ & \\
\hline Total & $442(48.8)$ & $464(51.2)$ & & $297(50.2)$ & $295(49.8)$ & & $68(41.7)$ & 95 (58.3) & & $63(48.1)$ & $68(51.9)$ & \\
\hline
\end{tabular}

MYC expression and patients' outcome. The high expression of MYC mRNA $(P=0.007$, Figure $1 \mathrm{~A})$ and $\mathrm{c}$-MYC protein $(P=0.001$, Figure $1 \mathrm{~B})$ were both significantly associated with poor patient BCSS. There remained significant differences with respect to positive c-MYC expression in the survival of patients in both Stage I $(P=0.016)$ and Stage II $(P=0.010)$ (Figures $1 \mathrm{C}$ and D) but not Stage III $(P=0.458)$ disease (data not shown).

Moreover, there was a significant association between positive c-MYC protein expression and shorter DM-free survival in unselected breast tumours $(P=0.017$, Figure $1 \mathrm{E})$, which was maintained in luminal A tumours $(P=0.013$, Figure $1 \mathrm{~F})$ but not in basal-like or HER2 + tumours (Figures $1 \mathrm{G}$ and H). c-MYC expression was associated with the development of bone metastases $(P=0.019)$ in unselected tumours, while in the luminal A population positive c-MYC expression was associated with liver metastases $(P=0.039)$.

In terms of adjuvant treatment, positive c-MYC expression significantly predicted a shorter DM-free survival in luminal A tumours treated with endocrine therapy $(P=0.002$, Figure 1I) but not in patients who did not receive adjuvant therapy (Figure 1J).

Additionally, the prediction of a shorter DM-free survival in luminal A tumours treated with adjuvant endocrine therapy was observed in LN + tumours (Figure $1 \mathrm{~K}, P=0.012$ ) but not in LN tumours (Figure 1L). In multivariate Cox regression analysis, c-MYC remained an independent predictor of a shorter DM-free survival in luminal $\mathrm{A} \mathrm{LN}+$ tumours treated with endocrine therapy $(P=0.013$, Table 3$)$.

Regulation of genes by MYC in biological subtypes. Top pairwise interactions for genes probe markers associated with MYC expression in ER-positive and -negative tumours showed several different hubs indicated to be highly influential or regulated in the MYC system.
In ER-positive disease, MYC mRNA was significantly associated with genes implicated in translational (initiation elongation and termination) together with cellular protein metabolism (Table 4). In addition, the high expression of MYC was associated with the downregulation of several key hubs, including genes for translocase of outer mitochondrial membrane 40 homolog (yeast)-like (TOMM4OL) and pre-B-cell leukaemia homeobox interacting protein 1 (PBXIP1; Figure 2A).

In contrast, within ER-negative disease, MYC mRNA was significantly associated with genes associated with glucose homeostasis, glucose metabolism and glucose transport (Table 4). $M Y C$ was also associated with upregulation by several genes of which calcium channel flower domain containing 1 (CACFD1) and proline dehydrogenase (oxidase) $1(P R O D H)$ were centralised hubs (Figure 2B).

\section{DISCUSSION}

Studies that address the prognostic significance of c-MYC protein and its influence on the response of therapeutic regimens are limited. In the current study, a large number of breast tumours were investigated for MYC mRNA and c-MYC protein expression in order to better understand the potential roles of this complex protein in BCs.

There is a wealth of studies that describe MYC amplifications in $\mathrm{BCs}$, although the frequency of this amplification is highly variable (Borg et al, 1992; Rummukainen et al, 2001; Robanus-Maandag et al, 2003; Schlotter et al, 2003; Adem et al, 2004; Al-Kuraya et al, 2004; Rodriguez-Pinilla et al, 2007; Cancer Genome Atlas Network, 2012). In this study, the expression of MYC that was observed in $13.2 \%$ of breast tumours is, however, in line with the large meta- 


\section{A}

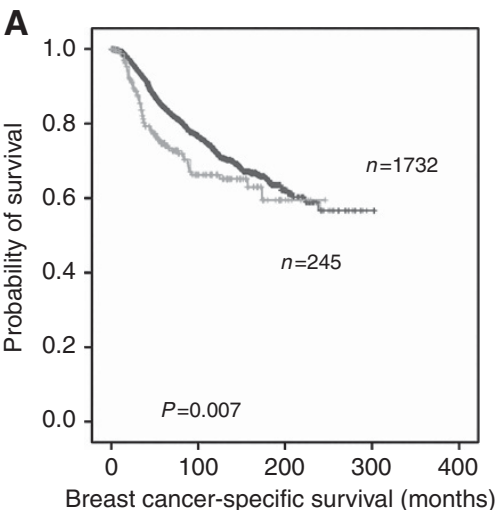

D

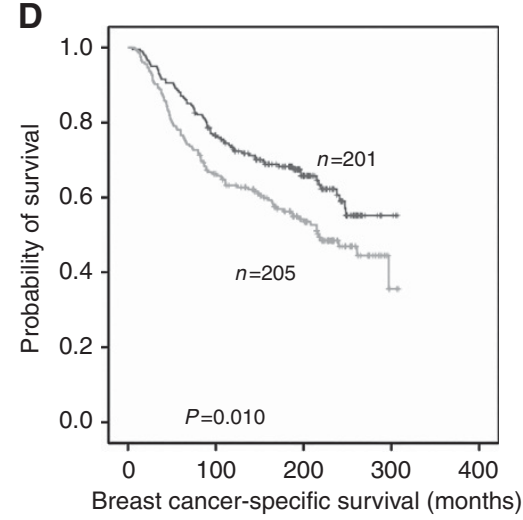

G

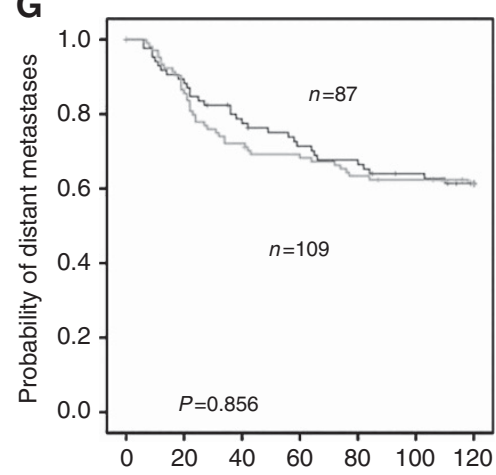

Distant metastases-free survival (months)

J

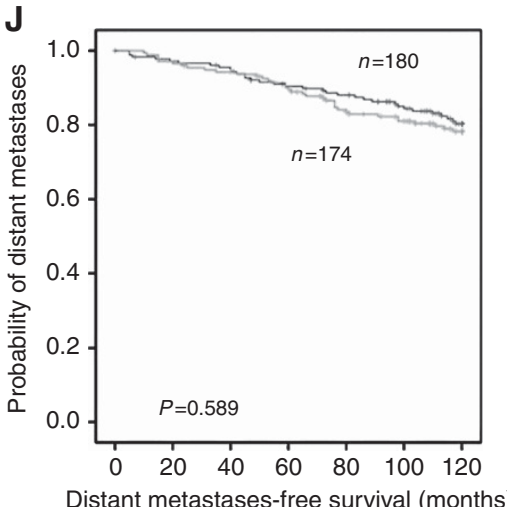

B

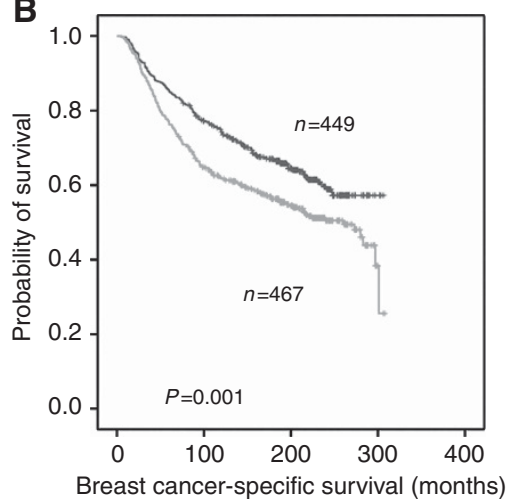

E

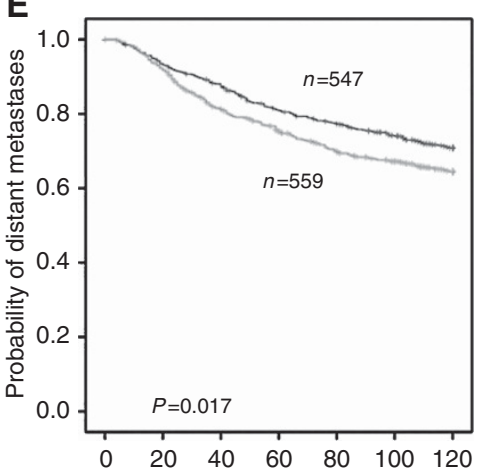

Distant mestastases-free survival (months)
C

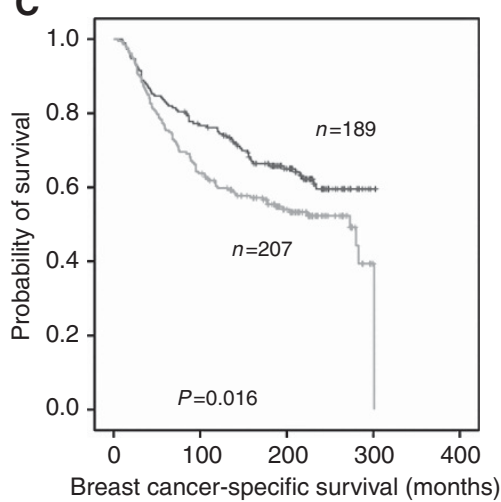

Breast cancer-specific survival (months)

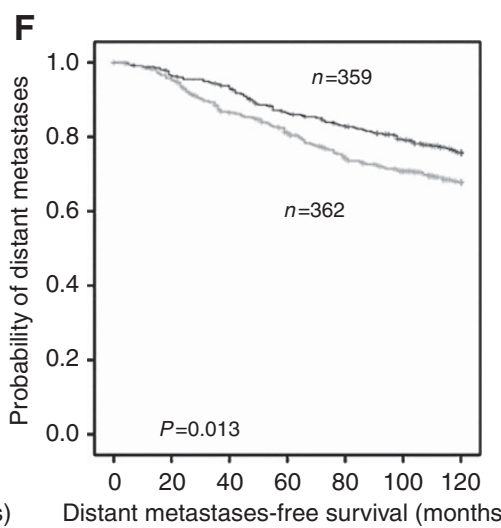

I

H
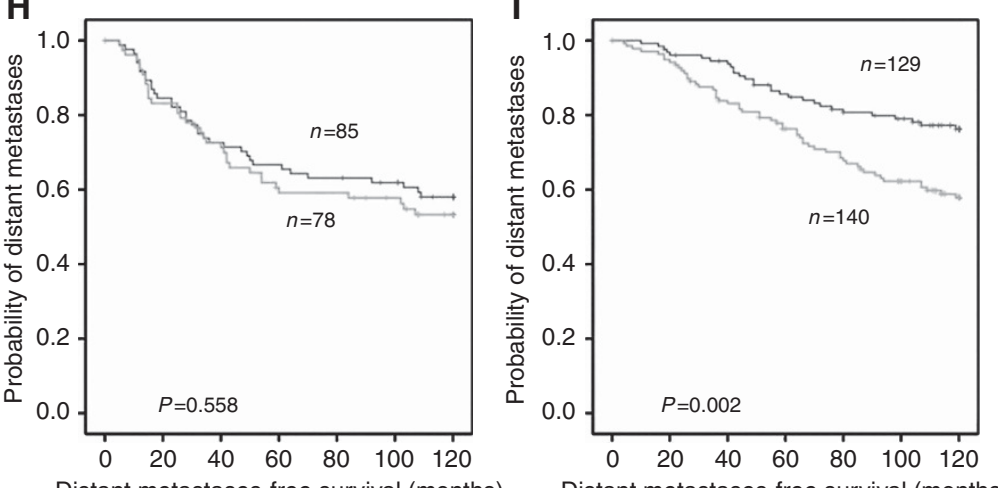

Distant metastases-free survival (months)
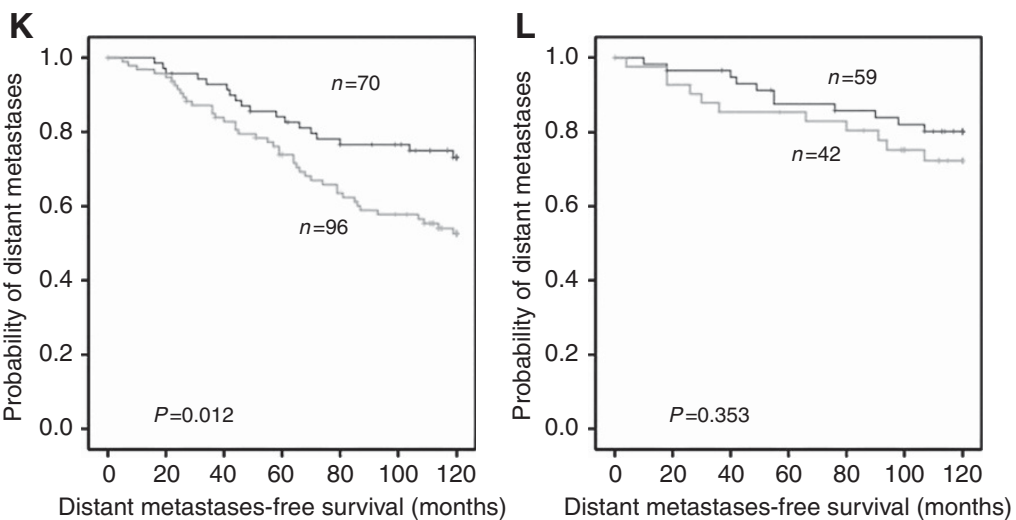

Figure 1. MYC and BC patient outcome: (A) MYC (BCSS), (B) c-MYC (BCSS), (C) c-MYC in Stage I disease (BCSS), (D) c-MYC in Stage II disease (BCSS), (E) c-MYC (DMFS), (F) c-MYC in luminal A tumours (DMFS), (G) c-MYC in basal-like tumours (DMFS), (H) c-MYC in HER2 + tumours (DMFS), (I) C-MYC in luminal A tumours treated with endocrine therapy (DMFS), (J) c-MYC in luminal A tumours with no adjuvant treatment (DMFS), (K) c-MYC in luminal A lymph node-positive patients treated with endocrine treatment, (L) c-MYC in luminal A lymph node-negative patients treated with endocrine treatment. Abbreviations: DMFS = distant metastases-free survival; Green = positive; blue = negative. A full color version of this figure is available at the British Journal of Cancer journal online. 
analysis study showing amplification of $M Y C$ in $15.7 \%$ of $\mathrm{BCs}$ (Deming et al, 2000). Additionally, MYC expression was similarly associated with higher tumour grade and poor patient survival as observed with MYC amplification (Deming et al, 2000).

Table 3. Multivariate analysis of c-MYC in luminal A lymph node-positive breast tumours treated with adjuvant endocrine therapy

\begin{tabular}{|c|c|c|c|}
\hline Parameter & Hazard ratio & $95 \% \mathrm{Cl}$ & $P$-value \\
\hline c-MYC & 1.86 & $1.06-3.26$ & 0.031 \\
\hline $\operatorname{Size}^{a}$ & 0.98 & $0.57-1.69$ & 0.943 \\
\hline Grade $^{a}$ & 3.64 & $1.96-6.76$ & 0.015 \\
\hline Stage & 3.64 & $1.96-6.76$ & 0.001 \\
\hline Age ( $\geqslant 50$ years) & 0.75 & $0.34-1.67$ & 0.481 \\
\hline
\end{tabular}

The expression of c-MYC protein was observed in $52.2 \%$ of invasive $\mathrm{BCs}$, which is within the range of other immunohistochemical studies (45-94\%) (Spandidos et al, 1989; Spaventi et al, 1994; Naidu et al, 2002). Although in this study the correlation between measurements of mRNA expression and those for protein expression was not perfect, MYC gene amplification has been reported to be significantly associated with overexpression of its mRNA and protein. Moreover, some authorities have reported MYC gene amplification in 15\% of breast tumours, whereas mRNA level was overexpressed in $22-35 \%$ of tumours. However, up to $40 \%$ of breast tumours showed MYC protein overexpression. These figures indicate that MYC overexpression could be attributed to different mechanisms, including gene amplification, transcriptional regulation and mRNA and protein stabilisation (reviewed in $\mathrm{Xu}$ et al, 2010). Therefore, variation between gene and protein expression is likely. When tumours were stratified according to histological type, medullary-like tumours showed the highest frequency of c-MYC expression, whereas most of the lobular carcinoma showed low c-MYC expression. This is consistent with

Table 4. Top pair-wise analysis of genes associated with high MYC expression in ER-positive and -negative breast tumours in the METABRIC data set and pair-wise correlation cross-validation in Breast Cancer Gene-Expression Miner

\begin{tabular}{|c|c|c|}
\hline Genes & Gene ontology_biological process & $\begin{array}{c}\text { Correlation with MYC using Breast Cancer } \\
\text { Gene-Expression Miner }\end{array}$ \\
\hline \multicolumn{3}{|c|}{ ER-negative tumours } \\
\hline AKT1 & Glucose homeostasis; glucose metabolic process; glucose transport & $P<0.0001(n=1560)$ \\
\hline FABP5 & Glucose transport & $P<0.0001(n=1353)$ \\
\hline FGFR4 & Glucose homeostasis & $P<0.0001(n=1502)$ \\
\hline FOXA1 & Glucose homeostasis & $P<0.0001(n=1526)$ \\
\hline IRS2 & Glucose metabolic process & $P<0.0001(n=1501)$ \\
\hline PTPN2 & Glucose homeostasis & $P<0.0001(n=1502)$ \\
\hline SEH1L & Glucose transport & $P<0.0001(n=1326)$ \\
\hline TFAP2B & Glucose homeostasis; glucose metabolic process & $P<0.0001(n=1355)$ \\
\hline CACFD1 & Calcium ion transmembrane transport & $P<0.0001(n=1282)$ \\
\hline PRODH & Proline catabolic process & $P<0.0001(n=582)$ \\
\hline \multicolumn{3}{|c|}{ ER-positive tumours } \\
\hline EIF4A1 & Translational initiation; cellular protein metabolic process & $P<0.0001(n=3834)$ \\
\hline EIF4H & Translational initiation & $P=0.04(n=3769)$ \\
\hline RPL13A & $\begin{array}{l}\text { Translational initiation; translational elongation; cellular protein metabolic process; } \\
\text { translational termination }\end{array}$ & $P<0.0001(n=3427)$ \\
\hline RPL17 & $\begin{array}{l}\text { Translational initiation; translational elongation; cellular protein metabolic process; } \\
\text { translational termination }\end{array}$ & $P<0.0001(n=3654)$ \\
\hline RPL18A & $\begin{array}{l}\text { Translational initiation; translational elongation; cellular protein metabolic process; } \\
\text { translational termination }\end{array}$ & $P<0.0001(n=3449)$ \\
\hline RPL8 & Translational initiation; translational elongation; cellular protein metabolic process & $P<0.0001(n=3710)$ \\
\hline RPL9 & $\begin{array}{l}\text { Translational initiation; translational elongation; cellular protein metabolic process; } \\
\text { translational termination }\end{array}$ & $P<0.0001(n=3453)$ \\
\hline RPLPO & $\begin{array}{l}\text { Translational initiation; translational elongation; cellular protein metabolic process; } \\
\text { translational termination }\end{array}$ & $P<0.0001(n=3518)$ \\
\hline RPS5 & $\begin{array}{l}\text { Translational initiation; translational elongation; cellular protein metabolic process; } \\
\text { translational termination }\end{array}$ & $P<0.0001(n=3653)$ \\
\hline EEF1B2 & Translational elongation; cellular protein metabolic process & $P<0.0001(n=3810)$ \\
\hline ATF3 & Cellular protein metabolic process & $P<0.0001(n=3714)$ \\
\hline СCT7 & Cellular protein metabolic process & $P<0.0001(n=4056)$ \\
\hline HSPD1 & Cellular protein metabolic process & $P<0.0001(n=3454)$ \\
\hline TUBB6 & Cellular protein metabolic process & $P<0.0001(n=3835)$ \\
\hline TOMM40L & Ion, protein and transmembrane transport & $P<0.0001(n=2418)$ \\
\hline PBXIP1 & Cell differentiation; negative regulation of transcription & $P<0.0001(n=3875)$ \\
\hline
\end{tabular}




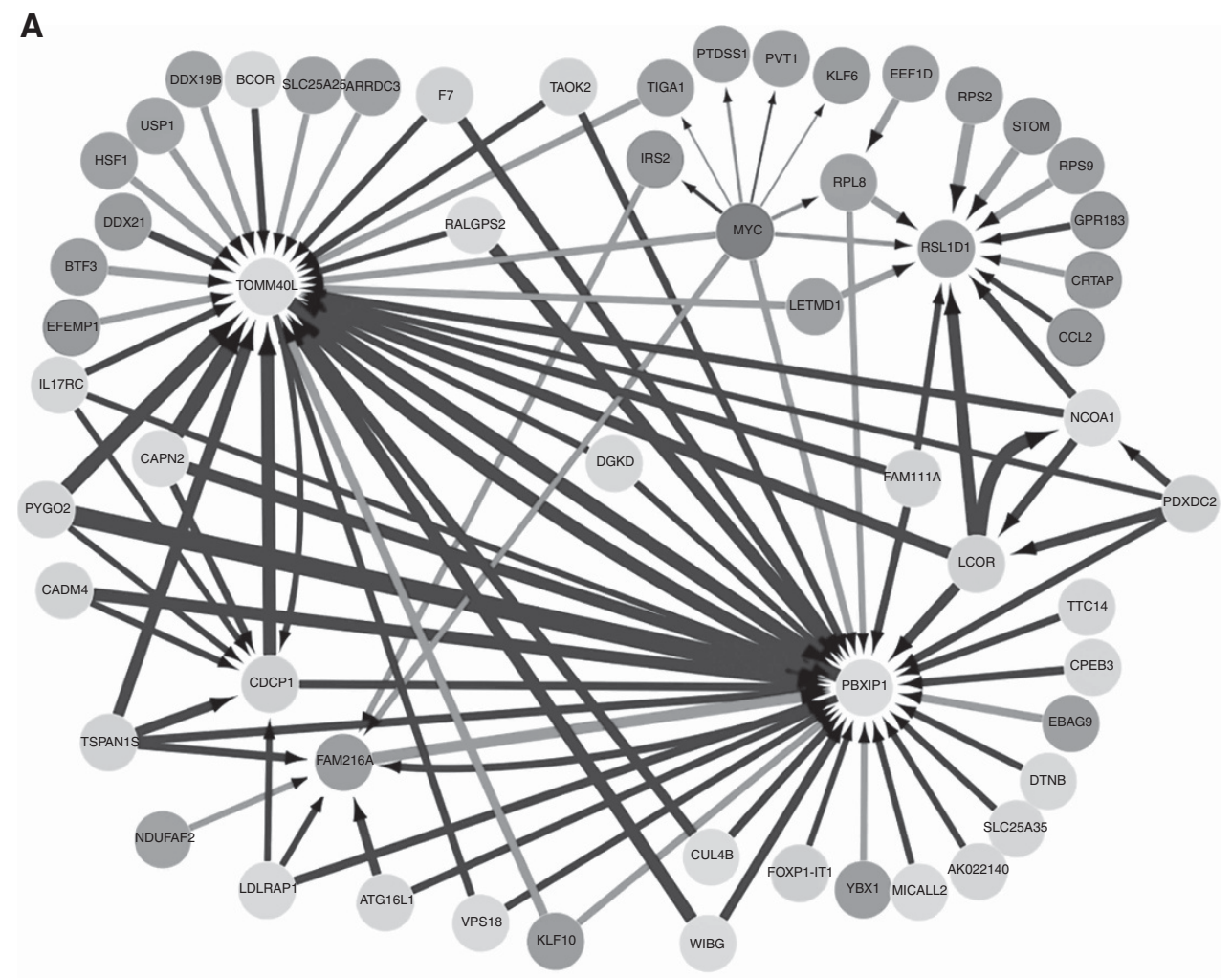

B

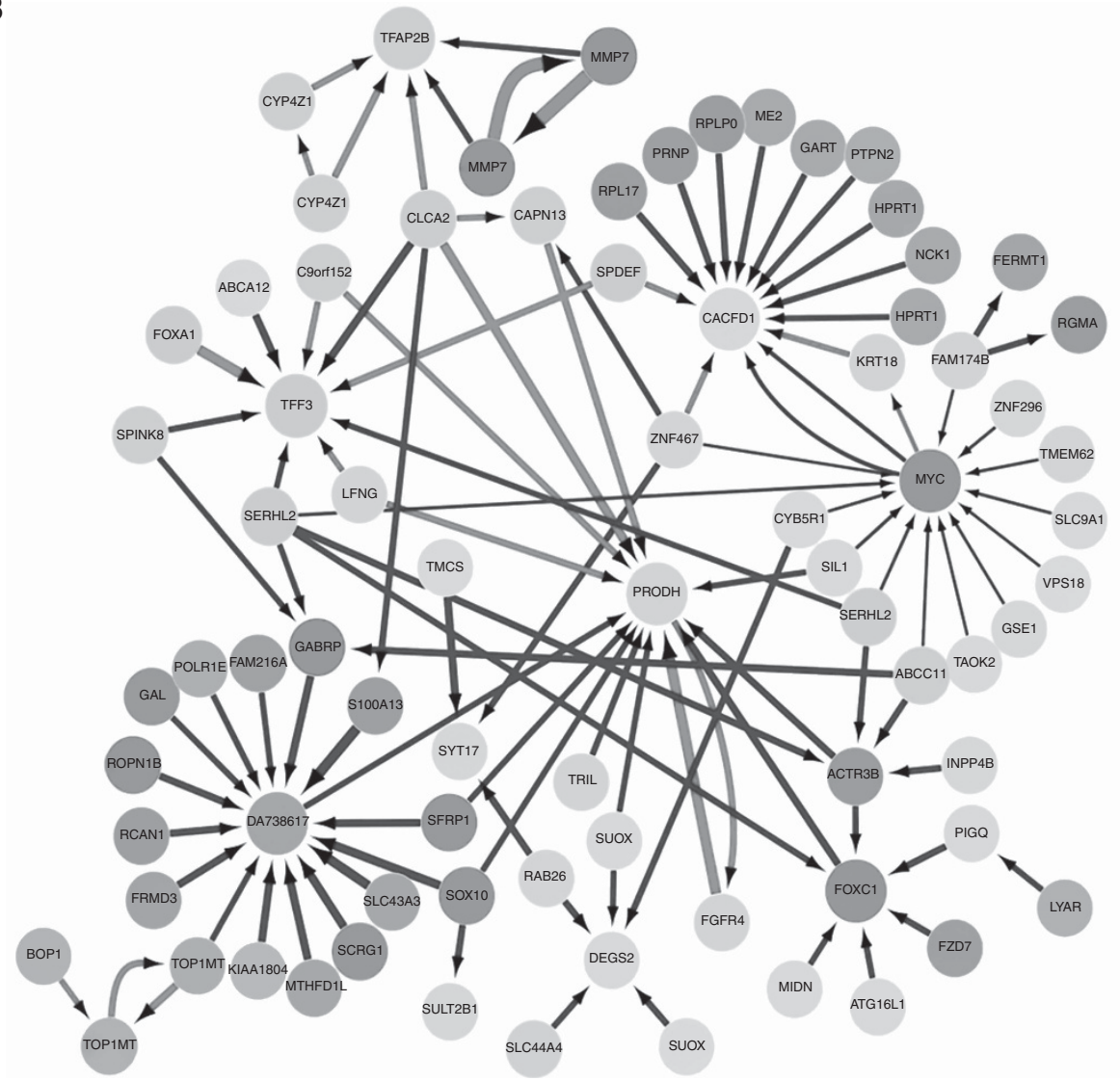

Figure 2. Gene interactions with MYC. Top pair-wise interactions for genes associated with MYC expression show hubs that are indicated to be highly influential or regulated in the MYC system in (A) ER-positive and (B) ER-negative disease. Each gene probe is represented by a node and the interaction weight between them as an edge, the width being defined by the magnitude of the weight. Interactions are directed from a source gene to a target gene as indicated by arrows. Red interactions indicate an excitatory interaction and blue indicates an inhibitory interaction. Red node gradient represents a positive fold change and green node gradient represents a negative fold change in the high MYC class. A full color version of this figure is available at the British Journal of Cancer journal online. 
previous studies that observed rare MYC amplification/c-MYC protein overexpression in lobular carcinomas, whereas it is more frequent in non-lobular breast carcinomas (Spaventi et al, 1994; Janocko et al, 2001).

In this study, high expression of MYC was associated with higher tumour grade and the basal-like phenotype. This is in agreement with previous clinicopathological studies (Deming et al, 2000; Liao and Dickson, 2000; Rummukainen et al, 2001; Naidu et al, 2002; Schmitt and Reis-Filho, 2002; Shanmugham et al, 2004; RodriguezPinilla et al, 2007; Cancer Genome Atlas Network, 2012). However, there was a lack of significant relation with tumour size or hormone receptor status; absence of these relationships have been demonstrated in previous studies (Spandidos et al, 1989; Naidu et al, 2002). These findings are not surprising in view of the multifunctional nature of MYC oncogene, with pivotal roles in proliferation, differentiation and cell death.

In the whole cohort, high MYC and c-MYC expression was associated with poor patient survival. Additionally c-MYC predicted a shorter metastatic-free survival, and this significance was maintained in multivariate analysis independently of tumour grade, nodal stage and size. Moreover, the relation between c-MYC and the development of resistance to antioestrogen treatment has been addressed in many studies (Santos et al, 1988; Venditti et al, 2002; McNeil et al, 2006; Planas-Silva et al, 2007; Musgrove et al, 2008) and is in agreement with our observations in relation between high c-MYC expression and shorter DM-free survival in those patients who received hormonal treatment and was an independent prognostic indicator for such group. Unlike RouxDosseto et al (1992), there was no significant association between tumour relapse and c-MYC expression in lymph node-negative patients. c-MYC protein may affect the response to chemotherapy probably through DNA damage response regulation (Berns et al, 1992a,b; Nass and Dickson, 1997; Gewirtz et al, 1998; Aulmann et al, 2006) although in the current study we found no evidence for this. Interestingly, MYC amplification in colon carcinoma predicts better response to 5-FU adjuvant chemotherapy (disease-free and cancer-specific survivals have been improved by $30 \%$ ) (Arango et al, 2001; Barratt et al, 2002) but only in p53 wild-type tumours. Although this type of study in BCs has not been published yet, Rakha et al (2007) described improvement of the poor prognosis of basal subtype of triple-negative BCs by treatment with chemotherapy. These tumours often have amplified EGFR gene (Reis-Filho et al, 2005) and according to the described MYC co-amplification in BCs (Al-Kuraya et al, 2004; Miura et al, 2008), and the association between c-MYC expression and basallike BCs, we may hypothesise the possibility that c-MYC overexpression may contribute to favourable response to chemotherapy, specially whose which contain 5-FU. Suppression of C-MYC transcription in BC cells after 5-FU treatment supports the direct effect of 5-FU on the oncogene activity, probably mediated by upstream signalling inhibition (Hernandez-Vargas et al, 2006).

We observed that c-MYC expression in luminal A tumours was associated with negative/low PI-3 kinase expression. Indeed, using a mouse BC model, PIK3CA-driven recurrent tumours with MYC amplification can lead to the inactivation of PIK3CA and remain independent of the PI-3 kinase pathway resulting in tumours developing resistance to PI-3 kinase pathway-specific targeted therapies (Liu et al, 2011). This could suggest that luminal A tumours, compared with other biological subtypes of BCs, are more susceptible to PI-3 kinase inhibitor resistance. Within luminal A tumours, high c-MYC expression was also associated with an increase in cell cycle activity indicated by high expression of Cyclin B1 and Ki67. Regulation of cyclin B1 is essential for the initiation of mitosis as it regulates the G2-M transition of the cell cycle. MYC regulates the CCNB1 gene promoter and the high expression of Cyclin B1 seen in the luminal A tumours, which has previously been associated with poor prognosis of hormone receptor-positive BCs ( $\mathrm{Hu}$ et al, 2006; Agarwal et al, 2009), is most likely as a consequence of this regulation.

In basal-like tumours, c-MYC expression was associated with Cyclin E and the cyclin-dependent kinase inhibitor p16. p16 has previously been associated with ER-negative BCs and poor patient outcome particularly those treated with adjuvant chemotherapy (Dublin et al, 1998; Han et al, 2001; Nemtsova et al, 2007). Both cyclin-E and p16 are inextricably linked with the G1-S-phase transition of the cell cycle. c-MYC is an upstream activator of cyclin-E/CDK2 activity and promotes cell cycle progression from G1 to $S$ phase independent of the Rb pathway and can compensate for low cyclin D/cdk4 kinase activity (Gray-Bablin et al, 1996; Alevizopoulos et al, 1997), whereas p16 arrests this transcriptional activity at the G1 phase. Rb is thought to promote an aggressive form of triple-negative BCs with MYC overexpression, although in the current study we found no evidence that RB was associated with c-MYC expression in any BC biological subtype (Knudsen et al, 2015). The p16 protein has a very long half-life (Sherr, 1996) and therefore accumulates in the cells with increasing number of cell cycles. This might partly explain high p16 expression in tumours with high growth fraction.

Although co-amplification of MYC and HER2 has previously been associated with very poor patient outcome in BCs by promoting a stem-like phenotype (Nair et al, 2014), we found no evidence to suggest this particularly as there was a negative relationship between MYC expression and HER2 status. We did, however, observe that in HER2 + tumours there was a significant relationship between c-MYC protein and high cell proliferation, as determined by Ki67, suggesting that co-expression is linked with more aggressive tumours. Conversely, there was also high correlation with the co-expression of c-MYC and ATM in HER2 +, suggesting that, while these tumours are highly proliferative, they are also undergoing higher levels of cell cycle arrest, DNA repair or apoptosis by MYC activating ATMdependent checkpoint responses (Guerra et al, 2010).

The mechanisms of MYC were further explored in ER-positive and -negative tumours using ANN analysis of the METABRIC data. Here we show that MYC is potentially driving glucose metabolism in ER-negative, but not in ER-positive, tumours providing necessary energy required for cell proliferation (the Warburg effect), a key feature of these poor prognostic tumours. It is well-documented that c-MYC regulates glucose metabolism and glutamine uptake and contributes to the metabolic preprogramming required for cancer cells to adapt to the tumour microenvironment (for reviews, see $\mathrm{Li}$ and Simon, 2013; Wahlstrom and Arsenian Henriksson, 2015). Our data confirm previous studies in triple-negative breast tumours where those with MYC gene copy gain have increased glucose uptake (Palaskas et al, 2011) and the expression of thioredoxin-interacting protein is downregulated driving the activation of glucose metabolism (Shen et al, 2015). A mechanistic association between MYC and glucose metabolism in endocrine resistance in BCs has also recently been described (Shajahan-Haq et al, 2014).

In ER-positive tumours, MYC was associated with translational function, particularly the family of ribosomal subunit proteins and eukaryotic translation-initiation factors. Increases in rRNA synthesis, ribosomal biogenesis and translational initiation/elongation are common cancer features, which can be driven by MYC (for a review, see Ruggero, 2009), and we show that enhanced ribosome assembly and transcriptional activity is a probable feature of luminal BCs.

\section{CONCLUSIONS}

Although MYC is multifunctional, it is apparent that different biological pathways are predominant in the separate molecular 
subtypes of BCs. The diverse mechanisms of c-MYC function as potential therapeutic targets, particularly in BC subtypes, therefore warrants further investigation.

\section{CONFLICT OF INTEREST}

The authors declare no conflict of interest.

\section{AUTHOR CONTRIBUTIONS}

ARG conceived the study, participated in its design and analysis and drafted the manuscript. MA participated in the analysis and interpretation; SE, CCN and MDR conducted the immunohistochemical studies; CC carried out the molecular genetic studies; DA and GB carried out statistical and ANN-based bioinformatics analysis; SM, RDM, IOE and EAR participated in its design, analysis and interpretation. All authors read and approved the final manuscript.

\section{REFERENCES}

Abd El-Rehim DM, Ball G, Pinder SE, Rakha E, Paish C, Robertson JF, Macmillan D, Blamey RW, Ellis IO (2005) High-throughput protein expression analysis using tissue microarray technology of a large well-characterised series identifies biologically distinct classes of breast cancer confirming recent cDNA expression analyses. Int J Cancer 116: 340-350.

Abdel-Fatah TM, Russell R, Agarwal D, Moseley P, Abayomi MA, Perry C, Albarakati N, Ball G, Chan S, Caldas C, Ellis IO, Madhusudan S (2014) DNA polymerase beta deficiency is linked to aggressive breast cancer: a comprehensive analysis of gene copy number, mRNA and protein expression in multiple cohorts. Mol Oncol 8: 520-532.

Adem C, Soderberg CL, Hafner K, Reynolds C, Slezak JM, Sinclair CS, Sellers TA, Schaid DJ, Couch F, Hartmann LC, Jenkins RB (2004) ERBB2, TBX2, RPS6KB1, and MYC alterations in breast tissues of BRCA1 and BRCA2 mutation carriers. Genes Chromosomes Cancer 41: 1-11.

Agarwal R, Gonzalez-Angulo AM, Myhre S, Carey M, Lee JS,

Overgaard J, Alsner J, Stemke-Hale K, Lluch A, Neve RM, Kuo WL, Sorlie T, Sahin A, Valero V, Keyomarsi K, Gray JW, Borresen-Dale AL, Mills GB, Hennessy BT (2009) Integrative analysis of cyclin protein levels identifies cyclin b1 as a classifier and predictor of outcomes in breast cancer. Clin Cancer Res 15: 3654-3662.

Al-Kuraya K, Schraml P, Torhorst J, Tapia C, Zaharieva B, Novotny H, Spichtin H, Maurer R, Mirlacher M, Kochli O, Zuber M, Dieterich H, Mross F, Wilber K, Simon R, Sauter G (2004) Prognostic relevance of gene amplifications and coamplifications in breast cancer. Cancer Res 64: $8534-8540$.

Albihn A, Johnsen JI, Henriksson MA (2010) MYC in oncogenesis and as a target for cancer therapies. Adv Cancer Res 107: 163-224.

Aleskandarany MA, Green AR, Benhasouna AA, Barros FF, Neal K, Reis-Filho JS, Ellis IO, Rakha EA (2012) Prognostic value of proliferation assay in the luminal, HER2-positive, and triple-negative biologic classes of breast cancer. Breast Cancer Res 14: R3.

Aleskandarany MA, Green AR, Rakha EA, Mohammed RA, Elsheikh SE, Powe DG, Paish EC, Macmillan RD, Chan S, Ahmed SI, Ellis IO (2010a) Growth fraction as a predictor of response to chemotherapy in nodenegative breast cancer. Int J Cancer 126: 1761-1769.

Aleskandarany MA, Rakha EA, Ahmed MA, Powe DG, Ellis IO, Green AR (2011) Clinicopathologic and molecular significance of phospho-Akt expression in early invasive breast cancer. Breast Cancer Res Treat 127: 407-416.

Aleskandarany MA, Rakha EA, Ahmed MA, Powe DG, Paish EC, Macmillan $\mathrm{RD}$, Ellis IO, Green AR (2010b) PIK3CA expression in invasive breast cancer: a biomarker of poor prognosis. Breast Cancer Res Treat 122: $45-53$.

Alevizopoulos K, Vlach J, Hennecke S, Amati B (1997) Cyclin E and c-Myc promote cell proliferation in the presence of p16INK4a and of hypophosphorylated retinoblastoma family proteins. $E M B O J \mathbf{1 6}$ : 5322-5333.

Arango D, Corner GA, Wadler S, Catalano PJ, Augenlicht LH (2001) c-Myc/p53 interaction determines sensitivity of human colon carcinoma cells to 5-fluorouracil in vitro and in vivo. Cancer Res 61: 4910-4915.

Aulmann S, Adler N, Rom J, Helmchen B, Schirmacher P, Sinn H.P (2006) cmyc amplifications in primary breast carcinomas and their local recurrences. J Clin Pathol 59: 424-428.

Barratt PL, Seymour MT, Stenning SP, Georgiades I, Walker C, Birbeck K, Quirke P. UKCCCR. Axis Trial Collaborators; Adjuvant X-ray and Fluorouracil Infusion Study. (2002) DNA markers predicting benefit from adjuvant fluorouracil in patients with colon cancer: a molecular study. Lancet 360: 1381-1391.

Barros FF, Abdel-Fatah TM, Moseley P, Nolan CC, Durham AC, Rakha EA, Chan S, Ellis IO, Green AR (2014) Characterisation of HER heterodimers in breast cancer using in situ proximity ligation assay. Breast Cancer Res Treat 144: 273-285.

Berns EM, Foekens JA, Van Putten WL, Van Staveren IL, Portengen H, de Koning WC, Klijn JG (1992a) Prognostic factors in human primary breast cancer: comparison of c-myc and HER2/neu amplification. J Steroid Biochem Mol Biol 43: 13-19.

Berns EM, Klijn JG, van Putten WL, van Staveren IL, Portengen H, Foekens JA (1992b) c-myc amplification is a better prognostic factor than HER2/ neu amplification in primary breast cancer. Cancer Res 52: 1107-1113.

Boddupally PV, Hahn S, Beman C, De B, Brooks TA, Gokhale V, Hurley LH (2012) Anticancer activity and cellular repression of c-MYC by the G-quadruplex-stabilizing 11-piperazinylquindoline is not dependent on direct targeting of the G-quadruplex in the c-MYC promoter. J Med Chem 55: 6076-6086.

Borg A, Baldetorp B, Ferno M, Olsson H, Sigurdsson H (1992) c-myc amplification is an independent prognostic factor in postmenopausal breast cancer. Int J Cancer 51: 687-691.

Cancer Genome Atlas Network (2012) Comprehensive molecular portraits of human breast tumours. Nature 490: 61-70.

Carroll JS, Swarbrick A, Musgrove EA, Sutherland RL (2002) Mechanisms of growth arrest by c-myc antisense oligonucleotides in MCF-7 breast cancer cells: implications for the antiproliferative effects of antiestrogens. Cancer Res 62: 3126-3131.

Chen Z, Wang Y, Warden C, Chen S (2015) Cross-talk between ER and HER2 regulates c-MYC-mediated glutamine metabolism in aromatase inhibitor resistant breast cancer cells. J Steroid Biochem Mol Biol 149: $118-127$.

Curtis C, Shah SP, Chin SF, Turashvili G, Rueda OM, Dunning MJ, Speed D, Lynch AG, Samarajiwa S, Yuan Y, Graf S, Ha G, Haffari G, Bashashati A, Russell R, Mckinney S, Group M, Langerod A, Green A, Provenzano E, Wishart G, Pinder S, Watson P, Markowetz F, Murphy L, Ellis I, Purushotham A, Borresen-Dale AL, Brenton JD, Tavare S, Caldas C, Aparicio S (2012) The genomic and transcriptomic architecture of 2000 breast tumours reveals novel subgroups. Nature 486: 346-352.

Dang CV (2012) MYC on the path to cancer. Cell 149: 22-35.

Deming SL, Nass SJ, Dickson RB, Trock BJ (2000) C-myc amplification in breast cancer: a meta-analysis of its occurrence and prognostic relevance. Br J Cancer 83: 1688-1695.

Dublin EA, Patel NK, Gillett CE, Smith P, Peters G, Barnes DM (1998) Retinoblastoma and p16 proteins in mammary carcinoma: their relationship to cyclin D1 and histopathological parameters. Int J Cancer 79: $71-75$.

Elsheikh S, Green AR, Aleskandarany MA, Grainge M, Paish CE, Lambros MB, Reis-Filho JS, Ellis IO (2008) CCND1 amplification and cyclin D1 expression in breast cancer and their relation with proteomic subgroups and patient outcome. Breast Cancer Res Treat 109: 325-335.

Gewirtz DA, Randolph JK, Chawla J, Orr MS, Fornari FA (1998) Induction of DNA damage, inhibition of DNA synthesis and suppression of c-myc expression by the anthracycline analog, idarubicin (4-demethoxydaunorubicin) in the MCF-7 breast tumor cell line. Cancer Chemother Pharmacol 41: 361-369.

Gray-Bablin J, Zalvide J, Fox MP, Knickerbocker CJ, Decaprio JA, Keyomarsi K (1996) Cyclin E, a redundant cyclin in breast cancer. Proc Natl Acad Sci USA 93: $15215-15220$.

Guerra L, Albihn A, Tronnersjo S, Yan Q, Guidi R, Stenerlow B, Sterzenbach T, Josenhans C, Fox JG, Schauer DB, Thelestam M, Larsson LG, Henriksson M, Frisan T (2010) Myc is required for activation of the ATMdependent checkpoints in response to DNA damage. PLoS One 5: e8924. 
Habashy HO, Rakha EA, Ellis IO, Powe DG (2013) The oestrogen receptor coactivator CARM1 has an oncogenic effect and is associated with poor prognosis in breast cancer. Breast Cancer Res Treat 140: 307-316.

Han S, Ahn SH, Park K, Bae BN, Kim KH, Kim HJ, Kim YD, Kim HY (2001) P16INK4a protein expression is associated with poor survival of the breast cancer patients after CMF chemotherapy. Breast Cancer Res Treat 70: 205-212.

Hernandez-Vargas H, Ballestar E, Carmona-Saez P, Von Kobbe C, Banon-Rodriguez I, Esteller M, Moreno-Bueno G, Palacios J (2006) Transcriptional profiling of MCF7 breast cancer cells in response to 5-Fluorouracil: relationship with cell cycle changes and apoptosis, and identification of novel targets of p53. Int J Cancer 119: 1164-1175.

Horiuchi D, Anderton B, Goga A (2014) Taking on challenging targets: making MYC druggable. Am Soc Clin Oncol Educ Book e497-e502; doi:10.14694/EdBook_AM.2014.34.e497.

Hothorn T, Hornik K, Zelis A (2006) Unbiased recursive partitioning: a conditional inference framework. J Comput Graphical Stat 15: 651-674.

Hu Z, Fan C, Oh DS, Marron JS, He X, Qaqish BF, Livasy C, Carey LA, Reynolds E, Dressler L, Nobel A, Parker J, Ewend MG, Sawyer LR, Wu J, Liu Y, Nanda R, Tretiakova M, Ruiz Orrico A, Dreher D, Palazzo JP, Perreard L, Nelson E, Mone M, Hansen H, Mullins M, Quackenbush JF, Ellis MJ, Olopade OI, Bernard PS, Perou CM (2006) The molecular portraits of breast tumors are conserved across microarray platforms. BMC Genomics 7: 96.

Janocko LE, Brown KA, Smith CA, Gu LP, Pollice AA, Singh SG, Julian T, Wolmark N, Sweeney L, Silverman JF, Shackney SE (2001) Distinctive patterns of Her-2/neu, c-myc, and cyclin D1 gene amplification by fluorescence in situ hybridization in primary human breast cancers. Cytometry 46: 136-149.

Jezequel P, Campone M, Gouraud W, Guerin-Charbonnel C, Leux C, Ricolleau G, Campion L (2012) bc-GenExMiner: an easy-to-use online platform for gene prognostic analyses in breast cancer. Breast Cancer Res Treat 131: 765-775.

Knudsen ES, Mcclendon AK, Franco J, Ertel A, Fortina P, Witkiewicz AK (2015) RB loss contributes to aggressive tumor phenotypes in MYC-driven triple negative breast cancer. Cell Cycle 14: 109-122.

Lancashire LJ, Powe DG, Reis-Filho JS, Rakha E, Lemetre C, Weigelt B, Abdel-Fatah TM, Green AR, Mukta R, Blamey R, Paish EC, Rees RC, Ellis IO, Ball GR (2010) A validated gene expression profile for detecting clinical outcome in breast cancer using artificial neural networks. Breast Cancer Res Treat 120: 83-93.

Li B, Simon MC (2013) Molecular pathways: targeting MYC-induced metabolic reprogramming and oncogenic stress in cancer. Clin Cancer Res 19: $5835-5841$.

Liao DJ, Dickson RB (2000) c-Myc in breast cancer. Endocr Relat Cancer 7: 143-164.

Liao DJ, Natarajan G, Deming SL, Jamerson MH, Johnson M, Chepko G, Dickson RB (2000) Cell cycle basis for the onset and progression of c-Myc-induced, TGFalpha-enhanced mouse mammary gland carcinogenesis. Oncogene 19: 1307-1317.

Liu P, Cheng H, Santiago S, Raeder M, Zhang F, Isabella A, Yang J, Semaan DJ, Chen C, Fox EA, Gray NS, Monahan J, Schlegel R, Beroukhim R, Mills GB, Zhao JJ (2011) Oncogenic PIK3CA-driven mammary tumors frequently recur via PI3K pathway-dependent and PI3K pathwayindependent mechanisms. Nat Med 17: 1116-1120.

McNeil CM, Sergio CM, Anderson LR, Inman CK, Eggleton SA, Murphy NC, Millar EK, Crea P, Kench JG, Alles MC, Gardiner-Garden M, Ormandy CJ, Butt AJ, Henshall SM, Musgrove EA, Sutherland RL (2006) c-Myc overexpression and endocrine resistance in breast cancer. J Steroid Biochem Mol Biol 102: 147-155.

Mcshane LM, Altman DG, Sauerbrei W, Taube SE, Gion M, Clark GM (2005) REporting recommendations for tumour MARKer prognostic studies (REMARK). Br J Cancer 93: 387-391.

Miura S, Nakashima M, Ito M, Kondo H, Meirmanov S, Hayashi T, Soda M, Matsuo T, Sekine I (2008) Significance of HER2 and C-MYC oncogene amplifications in breast cancer in atomic bomb survivors: associations with radiation exposure and histologic grade. Cancer 112: 2143-2151.

Musgrove EA, Sergio CM, Loi S, Inman CK, Anderson LR, Alles MC, Pinese M, Caldon CE, Schutte J, Gardiner-Garden M, Ormandy CJ, Mcarthur G, Butt AJ, Sutherland RL (2008) Identification of functional networks of estrogen- and c-Myc-responsive genes and their relationship to response to tamoxifen therapy in breast cancer. PLoS One 3: e2987.

Naidu R, Wahab NA, Yadav M, Kutty MK (2002) Protein expression and molecular analysis of c-myc gene in primary breast carcinomas using immunohistochemistry and differential polymerase chain reaction. Int J Mol Med 9: 189-196.

Nair R, Roden DL, Teo WS, Mcfarland A, Junankar S, Ye S, Nguyen A, Yang J, Nikolic I, Hui M, Morey A, Shah J, Pfefferle AD, Usary J, Selinger C, Baker LA, Armstrong N, Cowley MJ, Naylor MJ, Ormandy CJ, Lakhani SR, Herschkowitz JI, Perou CM, Kaplan W, O’toole SA, Swarbrick A (2014) c-Myc and Her2 cooperate to drive a stem-like phenotype with poor prognosis in breast cancer. Oncogene 33: 3992-4002.

Nass SJ, Dickson RB (1997) Defining a role for c-Myc in breast tumorigenesis. Breast Cancer Res Treat 44: 1-22.

Nemtsova MV, Zemliakova VV, Kuznetsova EV, Babenko OV, Zavalishina LE, Andreeva I, Bateva MV, Frank GA, Zaletaev DV (2007) [Analysis of the correlation between genetic and immunohistochemical markers (RB1, p16 and p53 gene regultors of a cell cycle) in sporadic mammary gland carcinoma]. Arkh Patol 69: 3-6.

Palaskas N, Larson SM, Schultz N, Komisopoulou E, Wong J, Rohle D, Campos C, Yannuzzi N, Osborne JR, Linkov I, Kastenhuber ER, Taschereau R, Plaisier SB, Tran C, Heguy A, Wu H, Sander C, Phelps ME, Brennan C, Port E, Huse JT, Graeber TG, Mellinghoff IK (2011) 18F-fluorodeoxy-glucose positron emission tomography marks MYC-overexpressing human basal-like breast cancers. Cancer Res 71: 5164-5174.

Patel JH, Loboda AP, Showe MK, Showe LC, Mcmahon SB (2004) Analysis of genomic targets reveals complex functions of MYC. Nat Rev Cancer 4: 562-568.

Planas-Silva MD, Bruggeman RD, Grenko RT, Smith JS (2007) Overexpression of c-Myc and Bcl-2 during progression and distant metastasis of hormone-treated breast cancer. Exp Mol Pathol 82: 85-90.

Rakha EA, El-Sayed ME, Green AR, Lee AH, Robertson JF, Ellis IO (2007) Prognostic markers in triple-negative breast cancer. Cancer 109: 25-32.

Rakha EA, Elsheikh SE, Aleskandarany MA, Habashi HO, Green AR, Powe DG, El-Sayed ME, Benhasouna A, Brunet JS, Akslen LA, Evans AJ, Blamey R, Reis-Filho JS, Foulkes WD, Ellis IO (2009) Triple-negative breast cancer: distinguishing between basal and nonbasal subtypes. Clin Cancer Res 15: 2302-2310.

Reis-Filho JS, Milanezi F, Carvalho S, Simpson PT, Steele D, Savage K, Lambros MB, Pereira EM, Nesland JM, Lakhani SR, Schmitt FC (2005) Metaplastic breast carcinomas exhibit EGFR, but not HER2, gene amplification and overexpression: immunohistochemical and chromogenic in situ hybridization analysis. Breast Cancer Res 7: R1028-R1035.

Robanus-Maandag EC, Bosch CA, Kristel PM, Hart AA, Faneyte IF, Nederlof PM, Peterse JL, van de Vijver MJ (2003) Association of C-MYC amplification with progression from the in situ to the invasive stage in C-MYC-amplified breast carcinomas. J Pathol 201: 75-82.

Rodriguez-Pinilla SM, Jones RL, Lambros MB, Arriola E, Savage K, James M, Pinder SE, Reis-Filho JS (2007) MYC amplification in breast cancer: a chromogenic in situ hybridisation study. J Clin Pathol 60: 1017-1023.

Roux-Dosseto M, Romain S, Dussault N, Desideri C, Piana L, Bonnier P, Tubiana N, Martin PM (1992) c-myc gene amplification in selected node-negative breast cancer patients correlates with high rate of early relapse. Eur J Cancer 28A: 1600-1604.

Ruggero D (2009) The role of Myc-induced protein synthesis in cancer. Cancer Res 69: 8839-8843.

Rummukainen JK, Salminen T, Lundin J, Kytola S, Joensuu H, Isola JJ (2001) Amplification of c-myc by fluorescence in situ hybridization in a population-based breast cancer tissue array. Mod Pathol 14: $1030-1035$.

Santos GF, Scott GK, Lee WM, Liu E, Benz C (1988) Estrogen-induced post-transcriptional modulation of c-myc proto-oncogene expression in human breast cancer cells. J Biol Chem 263: 9565-9568.

Schlotter CM, Vogt U, Bosse U, Mersch B, Wassmann K (2003) C-myc, not HER-2/neu, can predict recurrence and mortality of patients with node-negative breast cancer. Breast Cancer Res 5: R30-R36.

Schmitt FC, Reis-Filho JS (2002) Oncogenes, granules and breast cancer: what has c-myc to do with apocrine changes? Breast 11: 463-465.

Shajahan-Haq AN, Cook KL, Schwartz-Roberts JL, Eltayeb AE, Demas DM, Warri AM, Facey CO, Hilakivi-Clarke LA, Clarke R (2014) MYC regulates 
the unfolded protein response and glucose and glutamine uptake in endocrine resistant breast cancer. Mol Cancer 13: 239.

Shanmugham R, Gopalan R, Shanthi P, Krishnan KB (2004) Tumour angiogenesis and C-myc expression in breast carcinomas. Indian J Pathol Microbiol 47: 340-342.

Shen L, O'shea JM, Kaadige MR, Cunha S, Wilde BR, Cohen AL, Welm AL, Ayer DE (2015) Metabolic reprogramming in triple-negative breast cancer through Myc suppression of TXNIP. Proc Natl Acad Sci USA 112: 5425-5430.

Sherr CJ (1996) Cancer cell cycles. Science 274: 1672-1677.

Sierra A, Castellsague X, Escobedo A, Moreno A, Drudis T, Fabra A (1999) Synergistic cooperation between c-Myc and Bcl-2 in lymph node progression of T1 human breast carcinomas. Breast Cancer Res Treat 54: 39-45.

Smoot M, Ono K, Ideker T, Maere S (2011) PiNGO: a Cytoscape plugin to find candidate genes in biological networks. Bioinformatics 27: 1030-1031.

Spandidos DA, Yiagnisis M, Papadimitriou K, Field JK (1989) ras, c-myc and c-erbB-2 oncoproteins in human breast cancer. Anticancer Res 9: $1385-1393$.

Spaventi R, Kamenjicki E, Pecina N, Grazio S, Grazio S, Pavelic J, Kusic B, Cvrtila D, Danilovic Z, Spaventi S (1994) Immunohistochemical detection of TGF-alpha, EGF-R, c-erbB-2, c-H-ras, c-myc, estrogen and progesterone in benign and malignant human breast lesions: a concomitant expression. In Vivo 8: 183-189.

Venditti M, Iwasiow B, Orr FW, Shiu RP (2002) C-myc gene expression alone is sufficient to confer resistance to antiestrogen in human breast cancer cells. Int J Cancer 99: 35-42.

Vita M, Henriksson M (2006) The Myc oncoprotein as a therapeutic target for human cancer. Semin Cancer Biol 16: 318-330.

Wahlstrom T, Arsenian Henriksson M (2015) Impact of MYC in regulation of tumor cell metabolism. Biochim Biophys Acta 1849: 563-569.

Xu J, Chen Y, Olopade OI (2010) MYC and breast cancer. Genes Cancer 1: 629-640.

This work is published under the standard license to publish agreement. After 12 months the work will become freely available and the license terms will switch to a Creative Commons AttributionNonCommercial-Share Alike 4.0 Unported License.

Supplementary Information accompanies this paper on British Journal of Cancer website (http://www.nature.com/bjc) 